\title{
Inheritance of deficient tocopherol accumulation in sunflower seeds
}

\author{
L. DEL MORAL, B. PÉREZ-VICH, J. M. FERNÁNDEZ-MARTÍNEZ \\ and L. VELASCO* \\ Institute for Sustainable Agriculture (CSIC), Alameda del Obispo s/n, 14004, Córdoba, Spain
}

[Del Moral L., Pérez-Vich B., Fernández-Martinez J. M. and Velasco L. 2011 Inheritance of deficient tocopherol accumulation in sunflower seeds. J. Genet. 90, 489-491]

\section{Introduction}

Tocopherols are the main antioxidants in oil seeds and seed oils (Padley et al. 1994). They constitute a family of four compounds, named alpha-, beta-, gamma-, and deltatocopherol that exert antioxidant activity both in vivo, also known as vitamin $\mathrm{E}$ activity, as well as in vitro. Alphatocopherol is the form with maximum vitamin E effect (Traber and Sies 1996). Apart from its role as an antioxidant in the lipid phase of biomembranes, it has been suggested that alpha-tocopherol may play an important role in regulation of signalling cascades and gene expression (Azzi 2007). Unlike most oil seeds, which mainly accumulate gamma-tocopherol and delta-tocopherol (Padley et al. 1994), sunflower seeds mainly accumulate alpha-tocopherol, which account for more than $90 \%$ of the tocopherols in sunflower seeds and oils (Velasco et al. 2002).

The discovery of mutants with deficient accumulation of tocopherols has played an important role in the characterization of the tocopherol pathway (DellaPenna and Pogson 2006). The most relevant ones are the Zea maize mutant sxd1 (Provencher et al. 2001; Sattler et al. 2003) and Arabidopsis thaliana mutant vte 1 (Porfirova et al. 2002), which are devoid of tocopherols, and the Arabidopsis thaliana mutant vte5-1 (Valentin et al. 2006), with seed tocopherol levels reduced to $20 \%$ of the wildtype.

A natural sunflower mutant named IAST-522 with seed tocopherol levels reduced to $29 \%$ of the wildtype (73.4 mg per $\mathrm{kg}$ seed compared to $250.9 \mathrm{mg}$ per $\mathrm{kg}$ in the wildtype) has been identified (Velasco et al. 2010). This mutant is unique, as no other mutant with deficient tocopherol accumulation has been reported in sunflower. Therefore it is a valuable genetic source for studying biochemical and genetic aspects of tocopherol biosynthesis and accumulation in sunflower seeds. The objective of the present research was to

\footnotetext{
*For correspondence. E-mail: 1velasco@ias.csic.es.
}

study the inheritance of reduced seed tocopherol accumulation in seeds of the sunflower line IAST-522.

\section{Materials and methods}

\section{Plant materials}

IAST-522 is an $\mathrm{S}_{4: 5}$ sunflower line produced by a plant-torow selection scheme for reduced total seed tocopherol content, mainly in the alpha-tocopherol form ( $>95 \%$ of total tocopherols), from an accession with reduced seed tocopherol levels identified in the evaluation of a collection of cultivated sunflower entries (Velasco et al. 2010). HA89 is an oilseed maintainer line with standard seed tocopherol content and composition ( $>95 \%$ of total tocopherols in the alpha-tocopherol form) released by the Texas Agricultural Experiment Station and the USDA-ARS in 1971.

\section{Genetic study}

Plants of IAST-522 grown in pots in the greenhouse were reciprocally crossed with plants of HA89 in the winter of 2004 and 2005. $F_{1}$ plants together with plants of both parents were grown in pots in a mesh cage enclosure under open air conditions in the spring of 2005 and 2006, where reciprocal crosses as well as backcrosses to both parents were made. The heads of all plants were bagged before flowering to produce seeds under selffertilization. At harvest, six-seed bulk samples from each plant were analysed for total tocopherol content as described by Velasco et al. (2002).

Plants of the parents, $\mathrm{F}_{1}, \mathrm{~F}_{1 \mathrm{r}}, \mathrm{F}_{2}, \mathrm{BCP}_{1}$ and $\mathrm{BCP}_{2}$ generations produced in 2005 and 2006 were grown in the field in 2006 and 2007, respectively, in a randomized complete block design with two replications. $\mathrm{F}_{3}$ plants from an $\mathrm{F}_{2}$ plant population of 76 individuals were grown in the 2007 field plot, with $12 \mathrm{~F}_{3}$ plants per each $\mathrm{F}_{2}$. In all cases, seeds were germinated in moistened filter paper, sown in small pots, and transplanted to the field after three weeks in the growth chamber.

Keywords. sunflower; seed tocopherols; vitamin E; inheritance; heritability; Helianthus annuus L. 
The field plots consisted of rows 5-m long with $1 \mathrm{~m}$ spacing between rows and $0.20 \mathrm{~m}$ spacing between plants in the row. Analyses of tocopherol content of $\mathrm{F}_{1}, \mathrm{~F}_{2}, \mathrm{~F}_{3}$, and $\mathrm{BC}$ plants were conducted on six bulked $\mathrm{F}_{2}, \mathrm{~F}_{3}, \mathrm{~F}_{4}$, and $\mathrm{BC}_{1} \mathrm{~F}_{2}$ achenes, respectively, chosen at random.

\section{Heritability estimates}

Broad-sense heritability $\left(H^{2}\right)$ and narrow-sense heritability $\left(h^{2}\right)$ were estimated on a single-plant basis as (Allard 1960).

$$
\begin{aligned}
H^{2} & =\left(\sigma_{\mathrm{F}_{2}}^{2}-\left(\sigma_{\mathrm{P}_{1}}^{2}+\sigma_{\mathrm{P}_{2}}^{2}+\sigma_{\mathrm{F}_{1}}^{2}+\sigma_{\mathrm{F}_{1 \mathrm{r}}}^{2}\right) / 4\right) / \sigma_{\mathrm{F}_{2}}^{2} \\
h^{2} & =\left(2 \sigma_{\mathrm{F}_{2}}^{2}-\left(\sigma_{\mathrm{BCP}_{1}}^{2}+\sigma_{\mathrm{BCP}_{2}}^{2}\right) / \sigma_{\mathrm{F}_{2}}^{2},\right.
\end{aligned}
$$

where $\sigma_{\mathrm{F}_{2}}^{2}$, variance among $\mathrm{F}_{2}$ plants; $\sigma_{\mathrm{P}_{1}}^{2}$, variance among $\mathrm{P}_{1}$ (HA89) plants; $\sigma_{\mathrm{P}_{2}}^{2}$, variance among $\mathrm{P}_{2}$ (IAST-522) plants; $\sigma_{\mathrm{F}_{1}}^{2}$, variance among $\mathrm{F}_{1}$ plants of the cross HA89 $\times$ IAST$522 ; \sigma_{\mathrm{F}_{1}}^{2}$, variance among $\mathrm{F}_{1}$ plants of the cross IAST-522 $\times$ HA89; $\sigma_{\mathrm{BCP}_{1}}^{2}$, variance among plants from the backcross to $\mathrm{HA} 89 ; \sigma_{\mathrm{BCP}_{2}}^{2}$, variance among plants from the backcross to IAST-522. The minimum number of genes $(k)$ controlling the total tocopherol content was estimated following Wright (1968) as:

$$
k=\left(P_{1}-P_{2}\right)^{2} / 8\left(\sigma_{\mathrm{F}_{2}}^{2}-\left(\sigma_{\mathrm{P}_{1}}^{2}+\sigma_{\mathrm{P}_{2}}^{2}+\sigma_{\mathrm{F}_{1}}^{2}+\sigma_{\mathrm{F}_{1} \mathrm{r}}^{2}\right) / 4 \sigma_{\mathrm{F}_{2}}^{2}\right),
$$

where $P_{1}$ and $P_{2}$ are the mean values of the two parents.

Estimate of heritability through parent-offspring correlation was computed as the correlation coefficient between tocopherol content in the $F_{2}$ and $F_{3}$ plant generations. The use of the correlation instead of the regression coefficient is recommended when the parent and offspring generations are evaluated under different environments, as this method of estimating heritability tends to reduce environmental effects (Frey and Horner 1957).

\section{Results and discussion}

Seeds of line IAST-522 showed a low average tocopherol content in 2006 (74 mg per $\mathrm{kg}$ ) and 2007 (75 mg per $\mathrm{kg}$ ) as compared to the wildtype line HA89 (240 and $207 \mathrm{mg}$ per $\mathrm{kg}$, respectively). $\mathrm{F}_{1}$ plants from the cross IAST-522 $\times$ HA89 showed an average tocopherol content of $146 \mathrm{mg}$ per $\mathrm{kg}$ in 2006 and $124 \mathrm{mg}$ per $\mathrm{kg}$ in 2007, whereas $\mathrm{F}_{1}$ plants from the reciprocal cross showed an average tocopherol content of $118 \mathrm{mg}$ per $\mathrm{kg}$ in 2007 (table 1). The $\mathrm{F}_{1}$ generation from the cross HA 89 × IAST-522 could not be evaluated in 2006, as most $F_{1}$ plants produced no seeds or an insufficient number of seeds for tocopherol analysis. The results of 2007 indicated no significant differences $(t=0.75, P>0.05)$ between reciprocal $F_{1} s$, suggesting absence of cytoplasmic effects.

Mean and standard deviation values for the $\mathrm{F}_{2}$ and $\mathrm{BC}$ generations are presented in table 1 . Only 19 plants from the $\mathrm{BC}$ to IAST-522 produced sufficient number of seeds for tocopherol analysis in 2006, which was considered insufficient
Table 1. Total tocopherol content (mean $\pm \mathrm{SD}$; mg per $\mathrm{kg}$ seed) of sunflower lines HA89, IAST-522, their $F_{1}$ and $F_{2}$ generations, and the backcross to both parents, grown in Córdoba, Spain in 2006 and 2007, and estimates of broad-sense heritability $\left(H^{2}\right)$, narrow-sense heritability $\left(h^{2}\right)$, and minimum number of genes controlling the trait $(k)$.

\begin{tabular}{lcr}
\hline Generation & Year 2006 & Year 2007 \\
\hline HA89 & $240 \pm 26$ & $207 \pm 31$ \\
IAST-522 & $74 \pm 15$ & $75 \pm 18$ \\
F $_{1}$ (HA89xIAST-522) & - & $118 \pm 24$ \\
F1 $_{1}$ (IAST-522xHA89) & $146 \pm 26$ & $124 \pm 29$ \\
F $_{2}$ (IAST-522xHA89) & $154 \pm 52$ & $151 \pm 46$ \\
BC to HA89 & $182 \pm 41$ & $170 \pm 41$ \\
BC to IAST-522 & - & $128 \pm 39$ \\
$H^{2}$ & 0.81 & 0.67 \\
$h^{2}$ & - & 0.49 \\
$k$ & 1.55 & 1.62 \\
\hline
\end{tabular}

and accordingly $h^{2}$ could not be estimated in that year. Estimates of $H^{2}$ were 0.81 in 2006 and 0.67 in 2007. Estimate of $h^{2}$ in 2007 was 0.49 (table 1), indicating a major role of additive gene action. Estimate of heritability through parentoffspring correlation was 0.59 (figure 1). The estimate of the minimum number of genes underlying a deficient accumulation of tocopherols in seeds of IAST-522 was 1.55 in 2006 and 1.62 in 2007, suggesting that the trait is oligogenic.

There are no previous studies on the inheritance of deficient seed tocopherol accumulation in seeds of sunflower or other oilseeds. In rapeseed (Brassica napus L.), several inheritance studies have been conducted using breeding lines with different seed tocopherol levels. Goffman and Becker (2001a,b) concluded that total seed tocopherol content was mainly controlled by genes with additive effects, whereas Marwede et al. (2004) found low heritabilities (broad sense) for total seed tocopherol content, which ranged from 0.34 to

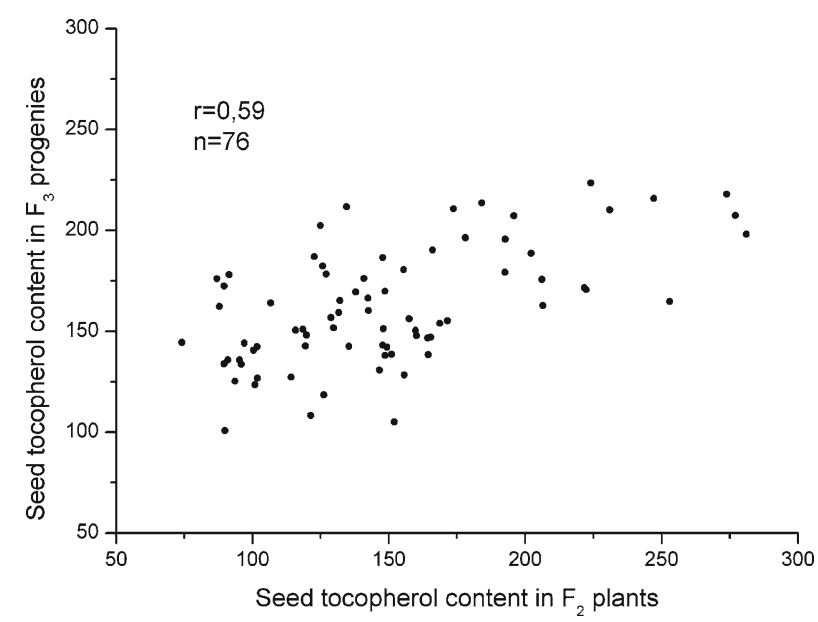

Figure 1. Scatter plot of total seed tocopherol content (mg per $\mathrm{kg}$ seed) of individual $F_{2}$ plants (bulked $F_{3}$ seeds) and their $F_{3}$ progenies (bulked $\mathrm{F}_{4}$ seeds in 12 individual $\mathrm{F}_{3}$ plants) from the cross between sunflower lines IAST-522, with reduced seed tocopherol content, and HA89, with wildtype seed tocopherol content. 
0.48 in three environments. The present research identified $H^{2}$ of 0.67 and 0.81 for reduced tocopherol content in seeds of IAST-522, indicating that the trait is highly heritable. The $h^{2}$ was estimated as 0.49 in 2007 compared to $H^{2}$ of 0.67 under the same environment, suggesting the predominance of additive gene action for this trait. Our results also suggested that reduced tocopherol content in seeds of the sunflower line IAST-522 is controlled by a relatively small number of genes, which is in line with the results obtained in previous studies on the inheritance of total seed tocopherol content in rapeseed (Goffman and Becker 2001b; Marwede et al. 2005).

In conclusion, the present research revealed that deficient tocopherol accumulation in seeds of sunflower line IAST522 is the result of genetic modifications in a relatively small number of genes, which results in a moderate-to-high heritability, with predominance of additive gene action. Although the breeding goal is to increase tocopherol content in sunflower seeds, the availability and characterization of a line with defective tocopherol accumulation is of great value for the identification of key genes involved in tocopherol accumulation in this crop.

\section{Acknowledgements}

L. Del Moral was the recipient of a grant from the FPI programme of the Spanish Ministry of Science and Innovation. The research was funded by FEDER funds (European Union), the Spanish Ministry of Science and Innovation (research project AGL2007-62834) and Dow Agrosciences LLC.

\section{References}

Allard R. W. 1960 Principles of plant breeding. John Wiley, New York, USA.

Azzi A. 2007 Molecular mechanism of $\alpha$-tocopherol action. Free Radic. Biol. Med. 43, 16-21.

DellaPenna D. and Pogson B. J. 2006 Vitamin synthesis in plants: tocopherols and carotenoids. Ann. Rev. Plant Biol. 57, 711-738.
Frey K. J. and Horner T. 1957 Heritability in standard units. Agron. J. 49, 59-62.

Goffman F. D. and Becker H. C. 2001a Genetic analysis of tocopherol content and composition in winter rapeseed. Plant Breed. 120, $182-184$.

Goffman F. D. and Becker H. C. 2001b Diallel analysis for tocopherol contents in seeds of rapeseed. Crop Sci. 41, 1072-1079.

Marwede V., Schierholt A., Möllers C. and Becker H. C. 2004 Genotipe $\mathrm{x}$ environment interactions and heritability of tocopherol contents in canola. Crop Sci. 44, 728-731.

Marwede V., Gül M. K., Becker H. C. and Ecke W. 2005 Mapping of QTL controlling tocopherol content in winter oilseed rape. Plant Breed. 124, 20-26.

Padley F. B., Gunstone F. D. and Harwood J. L. 1994 Occurrence and characteristics of oils and fats. In The lipid handbook (ed. F. D. Gunstone, J. L. Harwood and F. B. Padley), pp. 47-223. Chapman and Hall, London, UK.

Porfirova S., Bergmuller E., Tropf S., Lemke R. and Dormann P. 2002 Isolation of an Arabidopsis mutant lacking vitamin E and identification of a cyclase essential for all tocopherol biosynthesis. Proc. Natl. Acad. Sci. USA 99, 12495-12500.

Provencher L. M., Miao L., Sinha N. and Lucas W. J. 2001 Sucrose export defective1 encodes a novel protein implicated in chloroplast-to-nucleus signalling. Plant Cell 13, 11271141.

Sattler S. E., Cahoon E. B., Coughlan S. J. and DellaPenna D. 2003 Characterization of tocopherol cyclases from higher plants and cyanobacteria. Evolutionary implications for tocopherol synthesis and function. Plant Physiol. 132, 2184-2195.

Traber M. G. and Sies H. 1996 Vitamin E in humans: demand and delivery. Ann. Rev. Nutr. 16, 321-347.

Valentin H. E., Lincoln K., Moshiri F., Jensen P. K., Qi Q., Venkatesh T. V. et al. 2006 The Arabidopsis vitamin E pathway gene5-1 mutant reveals a critical role for phytol kinase in seed tocopherol biosynthesis. Plant Cell 18, 212-224.

Velasco L., Fernández-Martínez J. M., García-Ruíz R. and Domínguez J. 2002 Genetic and environmental variation for tocopherol content and composition in sunflower commercial hybrids. J. Agric. Sci. 139, 425-429.

Velasco L., Del Moral L., Pérez-Vich B. and Fernández-Martínez J. M. 2010 Selection for contrasting seed tocopherol content in sunflower seeds. J. Agric. Sci. 148, 393-400.

Wright S. 1968 Evolution and the genetics of populations, volume 1. University of Chicago Press, Chicago, USA. 